The Turkish Online Journal of Design, Art and Communication - TOJDAC

ISSN: 2146-5193, September 2018 Special Edition, p.1091-1096

\title{
CHARACTERISTICS PADDY FARMERS WHO DESIRE TO SELLING THEIR AGRICULTURAL LAND
}

\author{
Yogi Makbul, Sudrajati Ratnaningtyas, Pradono \\ Institut Teknologi Bandung. Jalan Ganesha 10. Bandung. 40132. Indonesia
}

\begin{abstract}
For the people of Indonesia, rice is the most important food, and the paddy is the main source of rice. Thus, paddy production is a very strategic issue for the Indonesian government. The largest paddy production in Indonesia is in West Java. The largest paddy production in West Java is Indramayu Regency. The largest district for paddy production is in Gantar District. Development in this area is very high because of the construction of a toll road through the area. The toll road's impact has increased the demand for business land. Because of this high demand, many farmers intend to Sell their land. If this phenomenon of land sales is not controlled, it will threaten the food security in Indonesia. This research aims to analyze the characteristics of the segment of farmers who desire to Sell their land. Knowing the characteristics of these farmers is useful for the government in conducting a regulation program to control land sales. The survey method is used, and the subject of this research is paddy farmers in the Gantar District, Indramayu Regency, Indonesia. Using cluster analysis, our research produces segments of the Selling farmer's characteristics. The results of the research indicate that the activity of the farmer's group is the characteristic that most influences the desire to Sell the land. The farmers who had no desire to Sell their land, most were involved in the farmer's group, but the farmer who desire Sell their land were generally less active. We recommend that governments create programs that enhance and expand the farmer groups to maintain food security
\end{abstract}

Keywords: Characteristics; Paddy Farmer; Sell; Farm land; Food security

\section{Introduction}

The paddy is important agricultural resource for the people of Indonesia. The largest source of calories within Indonesian society is the paddy, which produces more than 49 percent of calories (BPS Publication 2015). The largest area of paddy production in Indonesia in 2013 is West Java (BPS 2015). Thus, the province of West Java is the most important area in the context of food security in Indonesia; the regencies with the highest paddy production in West Java province are Indramayu Regency is the region with the largest paddy production in West Java (BPS Jabar 2014). The next highest paddy production is Gantar Districts (BPS Indramayu 2016) contains the districts that have the highest paddy production in Indonesia. Thus, this district has a very vital role in maintaining food security in Indonesia. However, paddy production in this area is being threatened because a toll road passes through in Gantar Districts.

The construction of toll roads in these districts will increase the number of purchases of paddy land. The area where toll roads will be located will no longer be able to support paddies; therefore, this decrease in land could lead to rising land prices of 30-60\% per year (Ariyani 2015). The price increase in paddy land will stimulate entrepreneurs to buy the land for resale or to use these areas as a non-agricultural business location. If this continues, it can lead to shrinking paddy land and eventually will reduce paddy production in this area.

Law No. 41 exists for sustainable land protection (BPN 2009); Article 44 paragraph 1 states that the land is forbidden to be transformed for use in non-food businesses. However, this law will be difficult to implement. At one time, the Karawang regency was the highest paddy producing region in Indonesia (Berita Indonesia 2007). However, currently, paddy production in that regency continues to decline, with the region now being surpassed by the Indramayu Regency. This decline was caused by the loss of paddy land in Karawang regency since the toll road was built. Between 1993 and 2003, depreciation was 181.7 ha of agricultural land per year. Most likely, the same thing will happen in Indramayu Regency in general and in the Gantar District.

Shrinkage of paddy land is difficult to prevent, but it can be blocked so that its speed is not so rapid that it cannot be controlled. The government is responsible for maintaining the nation's food security and should protect and control paddy land. The government cannot merely make rules, but it

Submit Date: 10.07.2018, Acceptance Date: 22.08.2018, DOI NO: 10.7456/1080SSE/149

Research Article - This article was checked by Turnitin

Copyright (C) The Turkish Online Journal of Design, Art and Communication 
must actively approach paddy farmers. Such an approach will ensure that farmers do not easily Sell their farms. Counseling can be effective if the characteristics of the segment of farmers who are likely to Sell their land are known.

\section{Literature Review}

To understand the process of how different variables, impact land conversion, a review of the literature needs to be conducted. In this literature review, we refer to previous studies that have been published in international journals.

(Zhang 2000) concluded that land conversion occurred because of the land market and the local government's policy in restraining land conversion. (Ding 2002) suggested that land conversion can be controlled with land reform policies, such as increasing land efficiency, rationalization of land allocation, land management, and coordination of the construction of villages and towns. (Tian dan Man 2008) concluded that the government may intervene to support land market development. (Imhoff, et al. 2004) concluded that urbanization is reducing food productivity in America. (Irwin and Geoghegan 2001) described the use of a spatial model to identify changes in land conversion. In this model, research considers only economic factors; moreover, it is difficult to determine the exact model. Their research concluded that conversion of land is a multidisciplinary process, with social factors playing a role in land conversion. (Deyong, et al. 2009) concluded that urbanization had destroyed the fertility of the soil and the surrounding forest. (Tan, et al. 2005) concluded that urbanization will eliminate 74 percent of arable land. The growth of small towns will eliminate agricultural land as they evolve into big cities. (Deng, et al. 2006) concluded that a 1.9 percent increase in land management will decrease agricultural productivity by 2.2 percent. (Xu, et al. 2007) concluded that urbanization reduces the productivity of land. (Plantinga dan Miller 2001) concluded that regional development would reduce the value of agricultural land. (Lambin, Rounsevell dan Geist 2000) used multiple models to predict changes in land use. Research on urbanization will provide a variety of impacts on the border region town and country. (Ramsey dan Corty 1982) concluded that conversion of agricultural land into non-agricultural land is influenced by increases in the population in urban areas, family income, and the paddy production of agricultural land. A state that there are two main types of factors that affect the conversion of agricultural to non-agricultural land: external and internal factors. External factors include industrialization, urbanization, public policy, and roads. Internal factors include land productivity and technology intensity.

\section{Research Methods}

We conduct our research on the segmentation characteristics of farmers who Sell their land. A segmentation in this study is a grouping based on similar characteristics. Thus, the survey will be administered to farmers in the research area. The interviews gathered information regarding how much the farmers desire to Sell their land; additionally, the characteristics of the farmers were subsequently gathered. The characteristics are grouped based on specific indicators. Furthermore, we make these results scalable so they can be analyzed and assigned a value. Variable in this research are (1) Desire to Sell land, (2) Age (3) Education (4) Activity of the farmer groups (5) Income (6) Sources of income (7) Number of family members (8) Number of plot Land area (9) Status of land (10) Distance of the land to the national road (11) Land fertility the price of land (12) The perception of income from agriculture (13) The desire of working outside agriculture (14) The desire to urbanization Perception of government support.

Furthermore, these data were analyzed through cluster analysis. This analysis seeks to examine segmentation by grouping farmers into segments based on similar characteristics. Segmentation is used for a program to correspond to the characteristics of the targets. For the number of segments to be optimal, the segments must be neither too small nor too large. If there are too few segments, the outreach program will not be effective because it will not correspond to the characteristics of the targets. If there are too many segments, they will generate many outreach programs. Although the programs might be appropriate based on the characteristics of the target, they would be expensive and inefficient. We used the statistical program SPSS to analyze the clusters in this study.

\section{Results}

After research data was collected, it was analyzed using the two-stage cluster method. Two

Submit Date: 10.07.2018, Acceptance Date: 22.08.2018, DOI NO: 10.7456/1080SSE/149

Research Article - This article was checked by Turnitin

Copyright (C) The Turkish Online Journal of Design, Art and Communication 
clusters were obtained using SPSS software to determine optimum similar characteristics. The $\mathrm{Z}$ score was determined for each variable, then the original value was changed to the value of the $Z$ score to equate the data units and increase the accuracy of the analysis. After average $Z$ scores for each variable in the first cluster and second cluster were obtained, we tested their significance using the unpaired difference test. Two assumptions, namely the equal variance assumption and the unequal variance assumption, were used. Thus, before testing common variance, the probability of retaining the null hypothesis was determined. If it was less than 0.05 , the revealed variances were not equal and the unequal variance assumption was used; otherwise, the equal variance assumption was used. A variable was declared to have a significant real effect when the probability of retaining the null hypothesis was less than 0.05 . Results are shown in Table 1.

Table 1. Cluster Analysis Results and Test Average Z Scores.

\begin{tabular}{|c|c|c|c|c|c|}
\hline \multirow[t]{2}{*}{ Variable } & \multirow{2}{*}{$\begin{array}{l}\text { Cluste } \\
r \\
1\end{array}$} & & \multirow[t]{2}{*}{ Var } & \multirow[t]{2}{*}{ Sig } & \multirow[t]{2}{*}{ Conclusion } \\
\hline & & 2 & & & \\
\hline $\begin{array}{l}\text { Desire to Sell his } \\
\text { agricultural land } \\
\text { (y) }\end{array}$ & -0.442 & 1.957 & $\begin{array}{r}\text { not } \\
\text { equal }\end{array}$ & $\begin{array}{r}0.00 \\
0\end{array}$ & $\begin{array}{l}\text { Significant. The second cluster } \\
\text { more desire to Sell his agricultural } \\
\text { land }\end{array}$ \\
\hline Age (x 1) & -0.038 & 0.167 & equal & $\begin{array}{r}0.15 \\
8\end{array}$ & $\begin{array}{l}\text { Not significant. The second cluster } \\
\text { higher age }\end{array}$ \\
\hline Education (x 2) & 0.028 & -0.122 & $\begin{array}{r}\text { not } \\
\text { equal }\end{array}$ & $\begin{array}{r}0.39 \\
2\end{array}$ & $\begin{array}{l}\text { Not significant. The second cluster } \\
\text { of lower education }\end{array}$ \\
\hline $\begin{array}{l}\text { Activity of the } \\
\text { farmer groups ( } x \\
\text { 3) }\end{array}$ & 0.212 & -0.937 & equal & $\begin{array}{r}0.00 \\
0\end{array}$ & $\begin{array}{l}\text { Significant. The second cluster of } \\
\text { lower farmer groups activities }\end{array}$ \\
\hline Income (x 4) & 0.072 & -0.318 & equal & $\begin{array}{r}0.00 \\
7\end{array}$ & $\begin{array}{l}\text { Significant. The second cluster of } \\
\text { lower income }\end{array}$ \\
\hline $\begin{array}{l}\text { Sources of } \\
\text { income }(\times 5)\end{array}$ & -0.006 & 0.025 & equal & $\begin{array}{r}0.83 \\
6\end{array}$ & $\begin{array}{l}\text { Not significant. The second cluster } \\
\text { of more income from agriculture }\end{array}$ \\
\hline $\begin{array}{l}\text { Number of family } \\
\text { members }(\times 6)\end{array}$ & 0.064 & -0.285 & $\begin{array}{r}\text { not } \\
\text { equal }\end{array}$ & $\begin{array}{r}0.05 \\
2\end{array}$ & $\begin{array}{l}\text { Not significant. The second cluster } \\
\text { number of the smaller members of } \\
\text { the family }\end{array}$ \\
\hline $\begin{array}{l}\text { Number of plot }(x \\
7)\end{array}$ & 0.030 & -0.134 & equal & $\begin{array}{r}0.25 \\
9\end{array}$ & $\begin{array}{l}\text { Not significant. The second cluster } \\
\text { of lower number of plot }\end{array}$ \\
\hline Land area (x 8) & -0.007 & 0.030 & equal & $\begin{array}{r}0.80 \\
2\end{array}$ & $\begin{array}{l}\text { Not significant. The second cluster } \\
\text { larger }\end{array}$ \\
\hline $\begin{array}{l}\text { Status of land } \\
(\times 9)\end{array}$ & -0.019 & 0.084 & $\begin{array}{r}\text { not } \\
\text { equal }\end{array}$ & $\begin{array}{r}0.56 \\
4\end{array}$ & $\begin{array}{l}\text { Not significant. The second cluster } \\
\text { status of land is more own }\end{array}$ \\
\hline $\begin{array}{l}\text { Distance of the } \\
\text { land to the } \\
\text { national road ( } x\end{array}$ & -0.109 & 0.483 & equal & $\begin{array}{r}0.00 \\
0\end{array}$ & $\begin{array}{l}\text { Significant. The second cluster } \\
\text { distance land closer to the national } \\
\text { road }\end{array}$ \\
\hline
\end{tabular}


The Turkish Online Journal of Design, Art and Communication - TOJDAC ISSN: 2146-5193, September 2018 Special Edition, p.1091-1096

\begin{tabular}{|c|c|c|c|c|c|}
\hline $\begin{array}{l}\text { Land fertility }(x \\
11)\end{array}$ & 0.022 & -0.096 & equal & $\begin{array}{r}0.41 \\
7\end{array}$ & $\begin{array}{l}\text { Not significant. The second cluster } \\
\text { of less fertile }\end{array}$ \\
\hline $\begin{array}{l}\text { The price of land } \\
(x 12)\end{array}$ & -0.168 & 0.746 & equal & $\begin{array}{r}0.00 \\
0\end{array}$ & $\begin{array}{l}\text { Significant. The second cluster of } \\
\text { land price are more expensive }\end{array}$ \\
\hline $\begin{array}{l}\text { The perception } \\
\text { of income from } \\
\text { agriculture (x13) }\end{array}$ & -0.057 & 0.251 & equal & $\begin{array}{r}0.03 \\
4\end{array}$ & $\begin{array}{l}\text { Not significant. The second cluster } \\
\text { are more good perception from } \\
\text { agricultural income }\end{array}$ \\
\hline $\begin{array}{l}\text { The desire of } \\
\text { working outside } \\
\text { agriculture }(x 14)\end{array}$ & 0.005 & -0.021 & equal & $\begin{array}{r}0.86 \\
3\end{array}$ & $\begin{array}{l}\text { Not significant. The second cluster } \\
\text { of perception work outside } \\
\text { agriculture is lower }\end{array}$ \\
\hline $\begin{array}{l}\text { The desire to } \\
\text { urbanization (x } \\
\text { 15) }\end{array}$ & -0.016 & 0.070 & equal & $\begin{array}{r}0.55 \\
9\end{array}$ & $\begin{array}{l}\text { Not significant. The second cluster } \\
\text { of more desire urbanization }\end{array}$ \\
\hline $\begin{array}{l}\text { Government } \\
\text { support (x 16) }\end{array}$ & -0.033 & 0.145 & $\begin{array}{r}\text { not } \\
\text { equal }\end{array}$ & $\begin{array}{r}0.72 \\
0\end{array}$ & $\begin{array}{l}\text { Not significant. The second cluster } \\
\text { of the perception of government } \\
\text { support is higher }\end{array}$ \\
\hline
\end{tabular}

Only the significant variables will be discussed. We concluded from the results that the variables significantly influencing the differences between clusters are: the desire to Sell the land $(\mathrm{p}$ value: 0.000 ), farmer group activity ( $\mathrm{p}$ value: 0.000 ), income ( $\mathrm{p}$ value: 0.007$)$, distance to the nearest national road ( $\mathrm{p}$ value: 0.000 ), and land price ( $\mathrm{p}$ value: 0.000 ).

\section{Discussion}

The socio economics characteristic that influence the desire to Sell their land are less active in farmer's groups, have low incomes, farm closer to national roads, and have greater land prices. Knowing these characteristics allows discussion about how they can be utilized to reduce the Selling of agricultural land.

Farmers who are less active in farmer's groups will have more desire to Sell their land. Thus, when a group of farmers increases their activity through developing new programs to attract less active farmers, hopefully the tendency to Sell the land will be reduced. The government has published Law No. 41 of 2009 to protect agricultural land for sustainable food. In Article 44 Paragraph one, this Act states that the food land cannot be sold for non-food activity. A control policy that allows Selling land only by juridical means will not be enough to reduce the Selling of agricultural land. It needs to be added to socialization programs for farmers. Increased activity in farmer socialization programs will be up to the farmers. If farmers understand the importance of food security in Indonesia, then they will remind each other who will Sell the land. Such activities will create social pressure on farmers and hamper the Selling of land.

Low income would make farmers want to Sell their land. This is natural because farmers need sufficient money to support their families. An increase in income from farming paddy can reduce their tendency to Sell their land. Article 39, Paragraphs one and two of Act No. 41 of 2009 revealed that the Central Government and local governments can provide incentives through a special budget allocation to coach farmers on sustainable food farming. Thus, the Central Government and local governments can implement programs granting incentives in the areas of sustainable food farm locations. Incentive programs can be implemented by granting subsidies through farmer's groups. The program will increase farming income so that the tendency to Sell land might subside. In addition, granting 
subsidies via farmer's groups will attract the farmers to activities in farmer's groups. These activities can be directed to provide an increased understanding of the importance of the Prevention Act and socialization of Act No. 41 of 2009. Improving their understanding can be implemented via farmer's groups. Once the farmers understand it, implementing the legislation will be easier. In this case, farmers will monitor fellow farmers and encourage them not to Sell the land. In addition, if outside parties wish to buy the land for non-farming purposes, members of the farmers group can report it to the government officer.

The distance the land is from a national road and its land price are two interrelated variables that will affect farmers' desires to Sell the land. Land closer to the road Sells for a greater price, obviously tempting farmers to Sell the land. At the time of this study, the national road was the Indramayu to Subang Regency, and construction of the toll road, Cikopo-Palimanan, was established. Once in place, the toll road will improve the land prices at least $30 \%$ per year, encouraging businessmen to buy the land around the highway to Sell back or use for business locations.

The Gantar District is the area's largest paddy producer, this location is most strategic for food security in Indonesia. This toll road will have a major impact on Selling agricultural land for nonfarming uses. More industrial zones and real estate will be created and built along the toll road. If not controlled, this will reduce paddy production in the most strategic areas in Indonesia.

Increasing farmers group mentoring programs in food farm locations with high productivity along highways and national roads, would reduce the Selling of farmland for non-agricultural uses. This program is very important in maintaining food self-sufficiency in Indonesia.

\section{Conclusions and Suggestions}

The main conclusion of this research is that the level of activity within farmer groups is the most influential factor for reducing farmers' desires to Sell Their Agricultural Land. Among the cluster of farmers who had no desire to Sell their land, participation in activity groups was higher than that in the cluster of farmers who desired to Sell their land.

The main suggestion for the government is to increase the number of activity groups for farmers. The government should increase its budget priorities for land paddies with high productivity throughout the area near toll roads. The increased activity in the farmer groups will be effective in the implementation of the complementary law "UU No. 41 Tahun 2009". These activities will monitor the farmers who do not carry out the Act; moreover, it can be used to maintain food security.

\section{References}

Ariyani, Fikri. "Harga Tanah di Sekitar Tol Cipali Bisa Meroket 20 Persen [Land prices Around Toll Could Rise about 20 Percent]." Liputan 6. 127 2015. http://bisnis.liputan6.com/read/ 2279767/harga-tanah-di-sekitar-tol-cipali-bisa-meroket-20-persen (diakses 3 10, 2016).

Azadi, Housein, P Ho, and L Hasfiati. "Agricultural land conversion drivers: A comparison between less developed, developing and developed countries. "Land Degradation \& Development (Wiley Online Libary) 22, no. 6 (2010): 596-604.

Berita Indonesia. Tak Bisa Hidup Tanpa Beras - Jutaan Hektar Sawah Dikonversi. 2007. http:// www.beritaindonesia.co.id/utama/776-tak-bisa-hidup-tanpa-beras?start=2 (accessed 25 , 2015).

BPN. "Undang-Undang Nomor 41 Tahun 2009 Tentang Perlindungan Lahan Pertanian Pangan Berkelanjutan [Law No. 41 of 2009 on the Protection of Agricultural Land Sustainable Food]." Badan Pertanahan Nasional [National Land Agency]. 2009. http://www.bpn.go.id/ Publikasi/Peraturan-Perundangan/Undang-Undang/undang-undang-nomor-41tahun-2009-888 (accessed 3 10, 2016).

BPS. Biro Pusat Statistik [Central Bureau of Statistics]. 2015. https://www.bps.go.id/linkTabelStatis/ view/id/1267 (accessed 12 31, 2015).

BPS Indramayu. Luas panen, Produktifitas, dan Jumlah Produksi Padi di Kabupaten Indramayu Tahun 2013 [Area harvested, Productivity, and Total Production of Rice in Indramayu in 2013]. 2016. https://indramayukab.bps.go.id/linkTabelStatis/view/id/13 (accessed 3 5, 2016).

BPS Jabar. Produksi Padi Menurut Kabupaten/Kota di Jawa Barat (Ton), 2009-2014 [Production of Paddy by Regency / City in West Java (Ton), 2009-2014]. 2014. http://jabar.bps.go.id/ linkTabelStatis/view/id/135 (accessed 74,2015 ). 
The Turkish Online Journal of Design, Art and Communication - TOJDAC ISSN: 2146-5193, September 2018 Special Edition, p.1091-1096

BPS Publication. "Konsumsi-Kalori-dan-Protein-Penduduk-Indonesia-dan-Provinsi-BerdasarkanHasil-Susenas-September-2015 [Consumption-Calorie-and-Protein-Population-Indonesiaand-Provincial-By-Results-Susenas-September-2015]." Biro Pusat Statistik [Central Bureau of Statistics]. 2015. https://www.bps.go.id/website/pdf_publikasi/Konsumsi-Kalori-dan-ProteinPenduduk-Indonesia-dan-Provinsi-Berdasarkan-Hasil-Susenas-September-2015_rev.pdf (accessed 2 28, 2016).

Deng, Xiangzheng, Zikun Huang, Scott Rozelle, and Emi Uchida. "Cultivated land conversion and potential agricultural productivity in China." Land Use Policy (Elsevier) 23, no. 4 (2006): 372-384.

Deyong, Yu, Shao Hongbo, Shi Peijun, Zhu Wenquan, and Pan Yaozhong. "How does the conversion of land cover to urban use affect net primary productivity? A case study in Shenzhen city, China." Agricultural and Forest Meteorology (Elsevier) 149 (2009): 2054-2060.

Ding, Chengri. "Land Reform Policy in China: Assesment and Prospects." Land Use Policy (Elsevier) 20 (2002): 109-120.

Imhoff, Marc L, et al. "The consequences of urban land transformation on net primary productivity in the United States." Remote Sensing of Environment (Elsevier) 89 (2004): 434-443.

Irwin, Elena G, and Jacqueline Geoghegan. "Theory, data, methods: developing spatially explicit economic models of land use change." Agriculture, Ecosystems and Environment (Elsevier) 85 (2001): 7-23.

Lambin, E.F, M.D.A Rounsevell, and H.J. Geist. "Are agricultural land-use models able to predict changes in land-use intensity?" Agriculture, Ecosystems \& Environment (Elsevier) 82, no. 3 (2000): 321-333.

Plantinga, Andrew J, and Douglas J Miller. "Agricultural Land Values and Value of Rights to Future Land Developtment." Land Economics (JSTOR), 2001: 56-67.

Ramsey, A. Frank, and Floyd L Corty. "Conversion of Prime Agricultural Land to Nonagricultural Uses in One Area of the Sunbelt." Journal of Agricultural and Applied Economics (Cambridge University Press) 14, no. 2 (1982): 23-29.

Tan, Minghong, Xiubin Li, Hui Xie, and Changhe Lu. "Urban land expansion and arable land loss in China a case study of Beijing-Tianjin-Hebei region." Land Use Policy (Elsevier) 22, no. 3 (2005): 187-196.

Tian, Li, and Wenjun Man. "Goverment Intervention in City Development in China." Land Use Policy (Elsevier) 26 (2008).

$X u, C, M L i u, S$ An, J.M Chen, and P Yan. "Assessing the impact of urbanization on regional net primary productivity in Jiangyin County, China." Journal of Environmental Management (Elsevier) 85, no. 3 (2007): 597-606.

Zhang, Tingweng. "Land Market Forces and Government's Role in Sprawl, the Cases in China." Cities (Elsevier) 17, no. 2 (2000): 123-135. 